\title{
Complexes (Ecogroups) of the Invertebrates, Phytomass and Dynamics of Microbiological Population and Their Importance at Grey-brown Soils Diagnostics in Azerbaijan
}

\author{
Hasanova Turkan Allahverdi \\ Institute of Soil Science and Agricultural Chemistry, National Academy of Sciences of Azerbaijan, Azerbaijan
}

Copyright (C) 2015 by authors, all rights reserved. Authors agree that this article remains permanently open access under the terms of the Creative Commons Attribution License 4.0 International License.

\begin{abstract}
The objective of this study was to examine the distribution of microorganism, invertebrates, phytomass in grey-brown (chestnut) soils of Garamaryam plateau. Comparative analysis of quantity of microorganisms, soil mezophauna and phytotesting in a phytocenoses and agrocenoses gave us important biodiagnostical results. The complexes (ecogroups) of the invertebrates in the natural and cultivated (cereals, clover) cenozes are comporatively studied with the purpose of their use as biodiagnostical test from grey-brown (chestnut) soils. The results show the quantity of invertebrates, herbs, microorganisms in a grey-brown soils of Garamaryam plateau.
\end{abstract}

Keywords Ecogroups, Trophic Structure, Quantity of Microorganisms, Phytotesting

\section{Introduction}

Soils contain a very high, but mostly unknown biodiversity and soil biology remains an under studied topic. Soil organisms are a key factor for soil development and in turn depend on soils as a habitat. Soils are home to a vast and still poorly known diversity of organisms that perform essential ecosystem function. A part of the nature which surrounds a living organizm and from which it interacts, creates an environment of the animal inhabiting. An organizm adaptation is revealed both up to standart and in a form of functioning community and ecological systems. The soil formation, the further complicated process develops under an influence of economical factor complex. A base of this process is a great geological and little biological cycle of the matter. $[1,2]$

Speaking about the soil formation factors, it is necessary to see those which V.V. Dokuchayev regarded as decisive and are possessing global importance. It is future V.R.
Wiliams distinguished two factors; relative age of soils and man's economical activity. [3]

Three main groups of the organisms-plants, microorganisms and animal participate in soil formation. At their joint life activities and also at the expense of the selected life atributes the most important sections of the soil formation creating a main quality of soil, its fertility are realized. The changing ecological factors can essentially influence not only on quantitative (a total number, biomass) and also on quntitative (grouping content) parameters of the soil invertebrate animals and microbiots but on their migration ability and selective attitude to possession of the food resources. The temperatural-humid conditions have an important significance in the soil invertebrates life on which their soil-forming activity depends.

The dark grey-brown soils of Karamaryam plateau occupy high foothill part of the Great Caucasus. These soils develop under different grassy- sorghum joints in the carbonatic crust of weathering. At enoughly long vegetative period of 195-255 days, arid-steppe fescue - stipa-sorghum, wormwood-wheatgrass and chestnut (grey-brown) soils are characterized relatively low productivity of the surface biomass-12-25 $\mathrm{c} / \mathrm{h}$ and some more root-21-34 $\mathrm{c} / \mathrm{h}$ masses in the foothill zone [3]. Analogously grey-brown soils of Azerbaijan in the spreading of these soils in Georgia the main vegetation is sorghum, stipa, wormwood here and there saltbushes. The sorghum associations which aren't found among vegetative of the chestnut soils in the moderate zone dominate. As is obvious from the conducted informations the grey-brown soils develop under characteristic arid-steppe vegetative conditions which can serve the important biodiagnostical parameters.

Under arid ecological condicions poykilotermic allows to avoid the surplus loss of moisture because an absence of possible differences between the body temperature and environment don't result in an extra evaporation. [5,6] Therefore, the invertebrates as habitats of the arid ecosystem 
bear better a high temperature and moisture deficite with the less energetic loss. As is obvious from this little analysis that the invertebrates complexes (groups, kinds, trophic structure) can be used as a biodiagnostical test at a research of the characteristical pecularities in the soils developing under arid ecological conditions. The biodiagnostical approach (on complex invertebrates) gains in importance and scientific actuality under investigations of the morphogenetic indications in the grey-brown (chestnut) soils of the Garamaryam plateau which extend in the Azerbaijan dry-steppe zone. In this region dominating abiotic factors of the environment (a high temperature, soil low humidity, insignifiant precipitations and so on) determine the life cycle of the soil invertebrates wholly depending on these situations.

Taking into account that majority of ecological factors are changeable in a space and time, at biodiagnostics of the grey-brown (chestnut) soils it is necessary to use of the indices on groupping (specific) composition and life cycle of the invertebrates more systematically and complexly. [4]

Understanding and maintaining biodiversity has become an increasingly important field of research, as well as a resource management goal. In soil microbial communities, maintaining critical functions may ultimately be more important than maintaining taxonomic diversity. One essential microbial function in soils in the processing and recovery of key nutrients from detrital inputs and accumulated soil organic matter. Soil microorganisms are actively involved in soil biochemical processes, including organic matter decomposition, nutrient mineralization and cycling. [2]

The decomposition of organic matter by soil organisms has an immense influence on soil fertility, plant growth, soil structure and carbon storage. Although microorganisms are the smallest forms of life, collectively they constitute the bulk of biomass on Earth and carry out many necessary chemical reactions for organisms. In the absence of microorganisms, higher life forms would never have evolved and could not now be sustained. Functional diversity used in the assessment of soil health as it relates to the activity of soil microflora involved in carbon cycling. Microorganisms are the backbone of all ecosystems. Microbes are decomposers, with the ability to recycle nutrients from other organisms waste products. These microbes play a vital role in biogeochemical cycles. Due to high soil heterogeneity, the spatial distribution of microbial metabolic activity is a key to understand functional variability of soil microhabitats. In addition, information regarding the spatial variability of soil microbial metabolic diversity, and the factors that determine these patterns could lead to more accurate predictions of microbial properties and functions.

The purpose of this study was to evaluate dynamics of microbial population, ecogroups of soil invertabres and phytotesting in the grey-brown (chestnut) soils.

\section{Objectives}

Materials of researches were grey-brown (Gypsic Calcisols in WRB) soils of arid zones. The researches were performed in the grey-brown (chestnut) soils of the Garamaryam plateau in Azerbaijan. [3]

The natural cenoz under different grassy-cereals-beans community (with the cereals predominating) and agrocenozes-irrigative grain and lucerne were selected as research objects. Taking into account that majority of ecological factors are changeable in a space and time, at biodiagnostics of the grey-brown (chestnut) soils it is necessary to use of the indices on groupping (specific) composition and life cycle of the invertebrates more systematically and complexly. The investigative grey-brown soils develop in the arid ecological conditions under natural vegetation, and also their surface (green) and subsoil (root) phytomass. In the recently irrigated soils, the exchangeable sodium percentage increases from depth of $30-40 \mathrm{~cm}$, the presence of exchangeable sodium and alkaline reaction lead to the development of solonetzic features in these soils. The plow horizon contains $4.5-5.0 \%$ humus. The humus content increases from the newly irrigated soils to the old-irrigated soils.

\section{Methods}

\subsection{Soil Invertebrates Investigation}

The researches were performed in the grey-brown (chestnut) soils of the Garamaryam plateau. The natural cenoz under different grassy-cereals-beans community (with the cereals predominating) and agrocenozes-irrigative grain and clover were selected as research objects. A registration of the soil invertebrates (mezophauna) was performed by a method of soil zoological exacavation in the natural and cultivated cenozes. The revealed invertebrates were systematized and united in the corresponding ecogroups.

\subsection{Phytomass Investigation}

The investigative grey-brown soils develop in the arid ecological conditions under natural vegetation, and also their surface (green) and subsoil (root) phytomass. Definition of the surface phytomass was performed by cutting of plants on soil surface and their following weigh with the size of $1 \mathrm{~m}^{2}$ in three-multiple on the registration area. At the same time with this area the plant fall which was taken into account at the definition of the total surface phytomass was collected. The underground mass was defined by a selection of the plant root through $10 \mathrm{~cm}$ to the depth of $30-50 \mathrm{~cm}$, and then their weight was corresponding depth, on the basis of the getting data on surface and underground mass the total productivity of the natural phytocenoz was determined. 


\subsection{Microbiological Analyses}

Formation of microbial cenoses and microbiological activity depends on many abiotic factors of hydrothermal regime of soil, its reaction and aeration conditions of mineral nutrition. If we consider that inhabit a wide variety of soil microorganisms having high physiological activity involved in complex biochemical processes, it is natural to study their activity in soils of arid ecosystems is of great relevance. From this perspective, we conducted a comparative study of microbiological parameters brown (grey-brown) soils natural cenosis (a cereal-grassland) vegetation and agrocenosis alfalfa.

Brown soils occur in dry-steppe zone of the republic with the arid environmental conditions. The conducted microbiological research has shown that qualitative and quantitative data in the overall data cenoses differ significantly.

For example, if the total number of microorganisms in the soil (0-30sm layer) natural cenosis of 3030.97 thousand. / g, the agricultural soils of alfalfa, these figures increase to 5329.04 thousand. / g.

For microbiological analyses soil samples were taken from $0-20 \mathrm{~cm}$ and $25-50 \mathrm{~cm}$ depth three times in a vegetation period June, August and October. The number of different groups of microorganisms were determined by the inoculation method. $1 \mathrm{~g}$ dry soil is dissolved in the water for analysis, it is diluted some times by taking $1 \mathrm{ml}$ from suspension $\left(10^{-5}\right.$ and $\left.10^{-6}\right)$. From the same suspension $1 \mathrm{ml}$ was planted in the standard nutrious environment. Incubation temperature was $28^{\circ} \mathrm{C}$, while incubation time depended on the tested group of microorganisms. The standard environment was used for definition of taxonomic group microorganisms: Ammonifier assimilating the organic forms of nitrogen were determined on meal-peptone agar (MPA). Spore-forming bacteria was determined in the heated mixed environment during 20 minutes in $80^{\circ} \mathrm{C}$. Bacteria assimilating the mineral forms of nitrogen were determined on the strach-ammonia agar (SAA). The total number of fungi was determined on malt agar (Czapek's agar medium) dilution of 1:1000. All microbiological analyses were performed in three replications and the average number of microorganisms was calculated at $1.0 \mathrm{~g}$ absolutely dry soil. The statistical pocessing of the data was performed by the routine methods to ensure a $95 \%$ significance level.

\section{Results}

\subsection{Soil Invertebrates}

Dominating and supplementary representatives of the invertebrates discovering in the natural and cultivated cenozes are united in the corresponding steppe and partially meadow ecogroups.

Predominance in a composition of the ecogroups in invertebrates steppe forms indicates the definite adaptation of the investigative soils to the chestnut type. The dominating groups are the followings: Tettigonidae; Hemiptera; Cerambucidae; Tenebrionidae; Coccinellidae; Gryllidae; Gastropoda; Arachnidae; Alleculidae.

The followings belong to the groups: Diptera; Isopoda; Lumbricidae; Carabidae; Curculionidae

\subsection{Phytotesting Results}

The conducted complex investigations in the natural phytocenoz of the Karamaryam plateau grey-brown (chestnut) soils showed that the kind (64 sorts) compositions of the plants belong to three main groups: various herb (Variherbatum), cereals (Craminecea), legume (Leguminosae). Phytoproductivity of natural phytocenoses forms $1727 \mathrm{~g} / \mathrm{m}^{2}$. The main components of the forming capacious phytomass are underground (root) mass $67.23 \%$, then surface (green) mass $23.62 \%$ and dead part of plants (fall) $9.15 \%$. Phytotesting in a complex with other physico-chemical, morpho-genetic data can be used as additional diagnostical parameter in grey-brown soils.

\subsection{Microbial Results}

Qualitative changes are also the group composition of the microbiota. On natural cenosis nonspore bacteria are from sheathe number $75.2 \%, 22.6 \%$, spore-forming bacilli, actinomycetes and fungi $24.1 \% 0.7 \%$. On the share of alfalfa agrocenoses nonsporeforming to $78.1 \%$ of bacteria and spore-forming bacilli $26.1 \%$ with a relative reduction of $21.5 \%$ actinomycetes and fungi $0.4 \%$.

In the irrigated grey-brown soils, the numbers of bacteria varied, from 1.1 to $1.5 \times 10^{6}$, spore forming bacteria from, 2 to $4.0 \times 10^{5}$, and microscopic fungi, from 2.2 to $3.1 \times 10^{3} \mathrm{CFU} / \mathrm{g}$ of dry soil in the spring-autumn periods during the first year of rotation.

\section{Discussion}

First of all it is necessary to comment that the diagnostical importance of the soil biota is a coincidence of the main ecological standards both soils and their animals inhabitants. Namely, such a conseptual approach allowed Gilyarov (1965) to elaborate zoological method of the soils diagnostics. Taking into consideration of the ecological, zoogeographic, physiological, production characterstics of the soils in habited by animals they can be used for arguable problems solution from soil geography (classifications and systematics) and also for revealing of the law objects in their formation and soil forming process direction. Thanks to the zoological method use a distribution of the animal forms (invertebrates) was studied in biogeocenozes and steppe zones of Siberia and other anological regions, where chernozems, chestnut, dark-chestnut brown and other desert-steppe soils Mordkovich, 1977. A special attention is paid to the soil diagnostics as a priority of question in Azerbaijan. It 
provides for an attraction at characteristics of the soil morphogenetic pecularities in the arid ecosystems besides phyto-chemical, minerological data and soil zoological (complexes of inventebrates, trophic structure, life activity of the separate groups and sorts) indices. In this context we should comment the investigations of the biological pecularities from the grey-brown, serozem-meadow, meadow-serozem, chestnut soils developing in the dry-steppe, subtropical, ecological conditions of the republic. Moreover a comparative and systematically-complex study of the biological characters with the soil salty composition, humus content, vegetation both in the natural and cultivated cenozes. We performed the further researches in the grey-brown (chestnut) soils of the Garamaryam plateau.

If the revealed groups are compared by themselves, then the predominating of the invertebrates among them can be revealed with the harder body covers of insects (Insecta), wood-louses (Isopoda), centipedes (Chilopoda), which are able to support the body water balance more efficiently in comparison with the groups of the body soft cover (Lumbricidae; Noctuidae) that it is so necessary for assimilation of the natural cenozes in grey-brown (chestnut) soils. The displaying representatives of the invertebrates in natural and cultured cenozes were united in the characteristic ecogroups that consequently take dominating or supplementary position corresponding a change of the elementary soil processes (hydrothermical regime, environment reaction and so on). The obtained data testify the prevalence of the steppe ecogroups which are more adapted to the summer season of a year (with a high temperature and low humidity of soils), in spring and autumn period an appearance of the definite representative meadow ecogroups is commented (rain worms, wood-louses, centipedes). Nevertheless, dominant of the steppe ecogroup invertebrates indicates a process of formation in steppe type of humus formation in this soil. Some dislocations of the steppe humus formation to the meadow type of humus formation are possible because of appearance of the meadow ecogroup characteristic representatives. However, dominant of the same groups and participation in a form of the supplementary groups indicates an existence of the change in the soil animal inhabitant qualitative (sorts) composition depending on changes of the soil-ecological and anthropogenic factors. Otherwise, at these factors change the stability of some or other ecogroup can possess a reverse character.

The research of phytoproductivity in the natural biocenoses was performed on separate seasons of the year: spring; summer; autumn what allowed to set up really a quantity forming phytomass in dependence of a ecological factors, but on the other hand to study mechanisms of adaptation in the separate kinds of plants to the arid conditions of the environment in the future. The performed collections of the natural vegetation in the key biotops and the next definition of their kind composition (specifying of the separate kind of plants was conducted on the book
“Azerbaijan Flora" 1950-1961., V.-I-VIII), showed that the natural phytocenoz was presented by 54 sorts belonging to three main groups: different grassy (Variherbatum); cereals (Craminecea); legume (Leguminosae).

Land use change is one of the greatest threats to biodiversity worldwide. The use of biogically balanced farming systems must be accompained by ecological and economic assesment of environmental changes the leading place belongs to soil microorganisms: The structure of the microbiological monitoring of the soil in biological farming is an important and necessary element in the management and preservation on fertility of agricultural land. Function and response of soil biocenosis on human intervention has both general laws for all types of soils and their zonal characteristics that are unique to a particular type of soil, which determines the need for research, particularly in view of zonal aspect.

\section{Conclusions}

A main purpose of these is a specification of the invertebrate complexes and their possible to the type with the characteristical steppe phytostructure. The conducted collection of the invertebrates and their grouping and specific accesory to the natural invertebrate with the characteristic life cycles. It was established that among the revealed invertebrates in the natural cenoz both dominating and groups (kinds) are commented. (Table 1)

The dominating groups are the followings: Tettigonidae; Hemiptera; Cerambucidae; Tenebrionidae; Coccinellidae; Gryllidae; Gastropoda; Arachnidae; Alleculidae.

The followings belong to the groups: Diptera; Isopoda; Lumbricidae; Carabidae; Curculionidae.

Table 1. Complexes (ecogroups) of the invertebrates in the natural cenoz

\begin{tabular}{|c|c|c|}
\hline Natural cenoz & Dominating groups & $\begin{array}{c}\text { Supplementary } \\
\text { groups }\end{array}$ \\
\hline $\begin{array}{c}\text { Different - cereals- } \\
\text { beans community } \\
\text { (with the } \\
\text { predominating } \\
\text { cereals) }\end{array}$ & $\begin{array}{l}\text { Tettigonidae; Hemiptera; } \\
\text { Cerambucidae; } \\
\text { Tenebrionidae; } \\
\text { Coccinellidae; Gryllidae; } \\
\text { Gastropoda; Arachnidae; } \\
\text { Alleculidae }\end{array}$ & $\begin{array}{c}\text { Diptera; } \\
\text { Isopoda; } \\
\text { Lumbricidae; } \\
\text { Carabidae; } \\
\text { Curculionidae; } \\
\text { Lepidoptera } \\
\end{array}$ \\
\hline
\end{tabular}

Cultivation of these soils and development of the irrigative agriculture (agricultural plants cultivation) essentially changed correlation of the invertebrate separate groups. An analysis of the revealing representatives of inventebrates showed that the dominating groups in agrocenoz cereals and clover are qualitatively distinguished from virgin soils (Table 2). Among the predominating groups in the cultivated cenozes the followings should be commented: Orthoptera; Hemiptera; Coccinellidae; Gryllidae; Noctuidae; Gastropoda; Carabidae; Scarabaeidae; Lumbricidae.

The followings belong to the groups: Isopoda; Arachnidae; Curculionidae; Diplopoda; Diptera. 
Table 2. Complexes (ecogroups) of the invertebrates in cereals agrocenozes and Lucerne

\begin{tabular}{|c|c|c|}
\hline Biocenozes & Dominating groups & $\begin{array}{c}\text { Supplementary } \\
\text { groups }\end{array}$ \\
\hline $\begin{array}{l}\text { Irrigative cereals } \\
\text { and lucerne }\end{array}$ & $\begin{array}{c}\text { Orthoptera; Hemiptera; } \\
\text { Coccinellidae; Gryllidae; } \\
\text { Noctuidae; Gastropoda; } \\
\text { Carabidae; Scarabaeidae; } \\
\text { Lumbricidae }\end{array}$ & $\begin{array}{l}\text { Isopoda; Arachnidae; } \\
\text { Curculionidae; } \\
\text { Diplopoda; Diptera }\end{array}$ \\
\hline
\end{tabular}

With the registration of the principles in the organism classification the revealing ecogroups of the invertebrates are subdivided on a character of nutrition in phytofags, saprophags and zoophags. In the natural cenozes the phytophags prevail, phyto-saprophags are optionally represented and partially beasts. In agrocenozes (cereals and clover) saprophags, phyto-saprophags and a few phytophags and beasts are among dominating invertebrates. (Table 3 )

Table 3. Trophic structure of the invertebrates in the investigated cenozes

\begin{tabular}{|c|c|}
\hline Cenozes & Trophic structure \\
\hline Natural cenoz & $\begin{array}{c}\text { Phytophags, phyto-saprophags, } \\
\text { zoophags }\end{array}$ \\
\hline $\begin{array}{c}\text { Agrocenozes- irrigative } \\
\text { cereals and lucerne }\end{array}$ & $\begin{array}{c}\text { Saprophags; phyto-saprophags; } \\
\text { phytophags; zoophags }\end{array}$ \\
\hline
\end{tabular}

Analyzing of the results on plant kind composition it is obvious that the dominating groups are cereals (Craminecea) $(40 \%)$ which are characteristic to the soils developing in the arid-steppe ecological situations, and on their accommodation mechanisms are adapted to the arid climatical factors. (Table 4)

Table 4. Groupping composition of the plant Karamaryam plateau natural phytocenoz

\begin{tabular}{|c|c|c|}
\hline Plants group & Kind quantity & $\begin{array}{c}\text { In \% of the total } \\
\text { quantity of sorts }\end{array}$ \\
\hline $\begin{array}{c}\text { Different herbs } \\
\text { (Variherbatum) }\end{array}$ & 28 & 48 \\
\hline Cereals (Craminecea) & 20 & 40 \\
\hline Legume (Leguminosae) & 6 & 12 \\
\hline Totality & 54 & 100 \\
\hline
\end{tabular}

The different herbs (Variherbatum) are presented with some more quantity of the sorts $48 \%$, nevertheless it consists of the separate insignificantly encountered plants belonging to the different families for example: complex-flower (Compositae); geranium (Ceraniaceae); crossflower (Cruciferae); lily (Liliaceae) and others. Among revealing plants the legumes are presented only 6 (six) sorts forming from the total quantity in all $12 \%$. In comparison with the plants of other families, legumes are less adapted to the arid environment and for their symbiotic relation with nitrogen fixing bacteria the most favorable soil-climatic conditions are required. Study of phytoproductivity in the grey-brown soils of Karamaryam plateau from which in important degree depends on its humus composition acquires an essential importance. Definition of phytomass in natural phytocenoz that main components forming productivity is: underground (root) mass, surface (green) mass and measuring plant part (fall). The total scheme and quantitative indices of the composite parts in the vegetative phytomass of natural phytocenoz are presented here.

Total phytomass: $1727 \mathrm{~g} / \mathrm{m}^{2}$. Underground (root) mass $1161 \mathrm{~g} / \mathrm{m}^{2}$, Surface (green) mass $408 \mathrm{~g} / \mathrm{m}^{2}$, Fall $158 \mathrm{~g} / \mathrm{m}^{2}$.

As is obvious from the figure an important part of the total phytomass falls on underground (root) mass $67.23 \%$, surface (green) mass forms $23.62 \%$, but in all $9.15 \%$ fall per dead plant parts. In the end all the components of the total phytomass in produced by natural vegetation under active activity of soil biota are drawn into complex biochemical process of humus formation. The getting data are wholly corresponded with the result of the investigations of the aforesaid scientists. Thus, the performed work testifies a great importance of the zones including in the Karamaryam plateau grey-brown (chestnut) soils.

Agriculture benefits from cycling of nutrients by microorganisms. For example, a number of major crop plants are legumes. Legumes live in close association with bacteria that form structures called nodules on their roots. In the root nodules these bacteria convert atmospheric nitrogen $\left(\mathrm{N}_{2}\right)$ into ammonia $\left(\mathrm{NH}_{3}\right)$ that the plant uses as a nitrogen source for growth. Nitrogen is one of the most important plant nutrient. Its deficiency of soil $\mathrm{N}$ immediately influences quantity and quality of crop yield.

\section{REFERENCES}

[1] Gilarov M.S. Zoological method of the soils diagnostics. Moscow 1965, p. 276

[2] Gilarov M.S. Registration of the large soil invertebrates (mezophauna). In a book of the soil-zoological researches. Moscow, Science, 1975 , p. 1-5

[3] Hasanova T.A., Samadov P.A. Phytotesting as a biodiagnostical indication of the grey-brown (chestnut) soils in the Garamaryam plateau. Europian Applied Sciences International Journal. Number 11, Germany, 2014, p. 3-5

[4] Hasanova T.A. Phytotesting in biological diagnostics grey-brown (chestnut) soils in the Gramaryam plateau. Euroasian Union of Scientists, $11^{\text {th }}$ International Scientific and Practical Conference Journal, Number 4, Moscow, 2015, p. $54-56$

[5] Samadov P.A. Environment physical factors and soils biological activity. In collection. Fundamental physical investigations in soil-science and melioration. M.Issue. MSU., 2003, p.194-198.

[6] Samadov P.A., Bababayova L.A., Aliyeva B.B., Mammadzadeh V.G., Sadikhova M.E., Aliyeva M.M. Biological indices and their importance in the diagnostics of the saline soils in Azerbaijan arid soils. A Journal News of Riazan state of Agrotechnical University named after Kostichev Flora V. I-VIII, 1950-1960, Baki, Issue. A.Azerbaijan SSR. 